\title{
Art of Acting and Management Style. Results of Psychological Research on Personality and Hierarchy of Values of Outstanding Polish Actors and Managers in the Area of Services
}

\author{
Barbara Mróz \\ Institute of Psychology, Faculty of Social Sciences, University of Opole
}

\begin{abstract}
The article - which is based on the need theory proposed by McClelland and the author's theoretical and empirical Personality and Axiological Model - deals with the research on two groups of professionally engaged individuals: outstanding Polish actors and managers in the area of services. The results obtained indicate a significant diversity of the groups in terms of personality traits and the hierarchy of values as well as the consistency of the image in the scope of significance of dimensions related to competence and autonomy. The sphere of motivation in both groups studied is remarkably similar as well. The results show that individuals who are effective and expect professional achievements, success and action, have a very strong and homogeneous internal motivation. In the case of people practising their profession in a creative manner in different disciplines, it is possible to single out not only the differences between them but also to determine the manner of social adaptations. The results obtained may be applied to activities aimed at professional development.
\end{abstract}

Keywords: outstanding Polish actors, managers, management style, personality, hierarchy of values, MOA

\section{Introduction}

Managing oneself (at the stage) and management of other(s) (projects and humans) are characterized by many specific and common attributes. In this 
paper the author makes an attempt to isolate them on the basis of the artistic activity area and business area (services), with attention paid to consistency of the theoretical approaches. It seems that for individuals who practise their profession in a creative manner in varied disciplines, it is possible to isolate certain differences (specificity) but also it is possible to determine similarities regarding problem-solving, functioning under pressure, skills to make decisions, etc. The assumption that it is possible to get mutual profits and to follow the way tasks are performed in the area of art and business is not only a theoretical proposal or an intent to contrast quite distanced realities.

It might turn out that there is a certain, unique positive transfer of skills, competences or actions worth being discovered. Effective functioning of an individual at work assumes an ability to learn and to transfer obtained skills from one situation into the other one which is seemingly not related (e.g. from art into business and vice-versa). Both of these different professional realities, as it seems, have been confronted for the first time in the area of psychology. All of the individuals who were surveyed meet a criterion of extraordinary professional engagement and they operate in a non-tangible area (art, services); hence, in this category they belong to one uniform group. The goal of the theoretical considerations and research was to establish the scope of similarities and differences between the artistic personality and the personality of a manger, as well as similarities and differences between their systems of values and to refer the results to the work style of both groups.

\section{Motivation to work as a common space for varied actions}

Comparing two different theoretical areas, a possible complementarity should be taken into account. Such an approach is presented by the motivation concept in psychology submitted by David McClelland, and the Vilfredo Pareto principle (80/20; the name originates from the Italian economist and sociologist Vilfredo Pareto) - in the area of management presented by Joseph Juran. One of the advantages of the interdisciplinarity is varied perception of a particular phenomenon and estimation of mutual profits.

McClelland's thesis $(1961,1973)$ that examination of general competences during work might result in new and important conclusions, has been proven. His analyses of competences as well as a wide range of skills, abilities, professional and interpersonal skills resulted in the isolation of three basic needs: a need for achievement, a need for affiliation and a need for power.

The first one, that is the need for achievement, is the strongest motivation to work. It can be defined as a will to be distinguished, successful and to get 
a competitive advantage. It promotes tasks requiring competition since, as a result, they are a source of success and feedback concerning the effectiveness of taken actions. It is the strongest need from the group of needs isolated by McClelland. For actors and managers, it may be important because of the related possibility of showing their skills compared to others (rivals), and because of the fact it means a prize resulting from better (more effective) completion of work (positive reviews of an actor, signing a contract by a manager). Commitment to goals of a performance or a company makes the need for achievement to give a chance to employees for personal growth and growth of the workplace. An effect of such an approach may be reinforcement and more and more frequent responsibility for undertakings and facing more and more demanding professional challenges. Worth mentioning is temporal acquisition of the growing specialized know-how and a chance for promotion (for an actor - new and more attractive proposals, higher remuneration, for a manager - a higher rank position and higher remuneration Strzałecki, 2010).

The realization of the need for achievement may also refer to the intrinsic power motivation. McClelland states it is promoted by widening freedom space and autonomy at a job. In fact, this assumption has been proven empirically when in a survey of a group of Polish managers it turned out that the factors having an impact on the efficiency and life quality satisfaction are autonomy and entrusting tasks important for a given company, as well as delegation of power (Mróz, 2011). The factors in question affect the team integration level, prove trust to the people, intent to strengthen professional ties with employees. An actor or a junior manager who has been trusted by his or her director or manager may have a strong feeling of obligation, ambition and a need to complete a new task as well as it is possible. These actions are fundamental and promote the need for affiliation which, according to McClelland (1985), is very important.

The need for affiliation is related with a desire to keep in touch with other individuals, and to be accepted. Surveys show that experts in the area of production, commerce and services who demonstrate an intensified need for affiliation are more successful compared to individuals focused on the tasks themselves. This is because the ability to keep professional inter-human relations consequently results in social support. A great role of the relation aspects is connected with this fact (Mróz, 2011; Martowska, 2012a). Nevertheless, it is worth mentioning that in a group of outstanding actors the impact of relations (meaning closeness with other individuals) on the feeling of the sense of life was not observed (Mróz, 2015). This diversity in both of the groups in this field is worth being confronted in the empirical part of this paper.

A need for authority isolated by McClelland is, to some extent, an effect of the previous needs, since having an impact on the environment can be effective 
in the case one has achievements and good relations with others. It should be emphasized that for actors the feeling of authority and influence is rather related with the social impact on spectators or critics of their artistic performance, and less with good relations with individuals (it could be said that because of the success such a contact might be even harder). In the group of managers, the feeling of authority and good relations with others have a different and reduced scope (Amabile, Pillemer, 2012).

Apart from the psychology area, worth mentioning is the Pareto principle of "a few key [factors], and numerous minor ones" well known in economics (Juran, 1974). It points out the share of considerable efforts (e.g. engagement) which, at the preliminary stage of action, result in poor effects. Later, the proportions reverse, e.g. $20 \%$ of engagement brings $80 \%$ of success. Obviously, the moment when the situation takes place is important, but it is hard to define it. The principle enables to determine priorities, it simplifies time management for oneself and for others, it has an impact on shortening tasks completion time and invested resources.

If at the beginning of their professional career an actor and a manager invest $80 \%$ of their energy and time in order to get $20 \%$ of the desired effect, they need to be asked about their needs for achievement, affiliation and authority, about their optimal saturation, proportions and consumed time. Later, along with the professional career growth, thanks to the lower labour input (20\%), they can achieve much larger effects (80\%).

This principle can be applied in the case of work of outstanding actors and effective managers. However, beside this principle, a huge diversity exists, both in the scope regarding the job form (an individual role at the stage versus project \& human resources management) and in the scope of becoming experienced. The aforementioned information can be illustrated by two quotations. One comes from an interview with Gustaw Holoubek, the second one with Ewa Błaszczyk.

"How do you prepare for a role? What is helpful and what disturbs you?

Alone, at home, when it is quiet. The first impression decides: what sort of a character it is, what I can express when playing it. I need to protect this first impression since rehearsals and the entire preparation process make me distanced from it. Hence, I am not a fan of the traditional rehearsal way, gradual acquisition of expression and varied interpretation proposals long time before the premiere. I revolt against it. What one gets from the progress of such a process is always worse than better. A thought is what decides everything and it's common that the best thinking takes place at peace and concentration" (Terlecka-Reknis, 2008, p. 121). 
"Maturing cannot be accelerated. A role matures exclusively at the theater stage. I cannot deal with it in my head and sitting in a chair. I must stand opposite a spectator. An actor is very sensitive to all signals originating from the audience. Good, otherwise he or she would play like a machine. Sometimes it's better not to finish a given part if the audience caught something earlier, or it is necessary to be made in another way than previously intended and prepared.

However, the next stage, when the role is well-known is very pleasant. I can benefit from a live touch with a spectator. Both of us feel that the space between us is not dead but it converts into a relationship, is takes a meaning" (Błaszczyk, Strączek, 2005, p. 109).

Psychologists' declaration that work focused on competences when doing one's job is the best source of the knowledge about the creation process and the work style, is confirmed by the afore statements.

The subsequent sub-section presents the criteria of the model applied to examine differences and similarities of personalities of outstanding Polish actors and managers.

\section{Personality and Axiological Model - assumptions and results}

The three-factor theoretical \& empirical Personality and Axiological Model (Model Osobowościowo-Aksjologiczny - MOA) of Barbara Mróz has been established on the basis of long-term human studies. This model was developed between 2009-2011 and it was inspired by: the theory of needs of Henry A. Murray (1938/2008), theory of essential needs of Richard M. Ryan and Edward L. Deci (2000), the adjustment concept by Julian B. Rotter (Rotter, Lah, Rafferty, 1992) and the role of isolated values - Milton Rokeach $(1967,1973)$.

After years of research into the personality structure and the system of values, by means of the factor analysis there have been determined elements constituting essential data of the model. The author, surveying varied groups of adults, found out that these elements are universal and such variables as age, sex, position or profession may supplement the knowledge about examined individuals (Mróz, 2008, 2011, 2015). The main personality dimensions, according to MOA are: competences, relationships and autonomy as well as adjustment, delegation of power and values (mature love and material support of the family).

The dimensions representing the MOA in the strongest way in terms of their load of factors - competences, relations and autonomy - were defined in the 
following way. Competences are a reflection of the knowledge, needs and skills to have an impact on the course of events, acceptance of efforts intended to achieve a goal, and they regard the effects of taken actions. The relationship aspect combines needs and skills of getting in touch with individuals, care for them and a need for social relations with consideration for one's internalized system of values. Social relations are determined on the basis of categories of responsibility and adjustment. Autonomy reflects the need and skills to act having a feeling of freedom and awareness of choice, self-confidence, cognitive bravery and a scope of hobbies.

The aspect of competences, relations and autonomy constitute one of the basic groups of variables in the MOA and it has the largest impact on the feeling of the quality and sense of life. Isolated elements are characterized by a relatively even saturation of the output variables for particular factors (pictured by factor loads) and they make a clear and visible psychological sense.

What is interesting, in the Adjective Test List used for the need of the aforementioned analyses (confirmation and exploration), also the personal adjustment scale exists. It is important, since it is possible to analyze a correlation between the results of the adjustment scale and the adjustment level. Rotter's theory and its operationalization in the form of the Sentence Completion Tests enable to determine a quantitative indicator which is the adjustment rate. In Rotter's understanding, adjustment is a reflection of high quality of life, a synonym of dealing well with difficulties and an ability to get into and to keep satisfactory relationships with individuals.

Adjustment functions are also found in the axiology sphere, which was mentioned by the author of the values scale applied to surveys in the MOA Rokeach (1973). Social adjustment may be recognized in two ways: as playing social roles or as a balance between the needs of a human and the conditions of the environment where he/she functions. Hence, in particular for an actor, realization of his/her social needs and meeting of others' needs by means of art (and due to art) are basic adjustment mechanisms. Emphasizing this fact is valuable since cooperation, activities, co-creation of culture values result in benefits for all the parties involved in this process.

\section{Characteristics of methods, description of the surveyed group, the survey procedure}

The main hypothesis established herein is based on the assumption of similarities in the scope of competences and autonomy (dimensions) as well as diversity in the area of relationships (MOA) and the system of values in groups 
of outstanding Polish actors and managers (representing the services area). The hypothesis is based on the subject-matter literature (Rokeach, 1973, 1979; Nosal, 2001; Strzałecki, 2010; Mróz, 2008, 2015). Services are a distribution of non-tangible goods and they are a sector of the economy close to the area of art.

The secondary hypothesis indicates the existence of a positive transfer of skills, competences or performance based on similar personality traits in the varied surveyed groups.

In order to verify the hypotheses, the following psychological tools were applied: ACL (Adjective Check List Manual), developed by Harrison G. Gough and Alfred B. Heilbrun (2012; Martowska, 2012b) and VS (Value Survey) - by Milton Rokeach (Rokeach, 1967, 1973; Brzozowski, 1989).

The survey technique was similar to the accepted one for the particular methods. Developed instructions were strictly followed. The surveys of outstanding actors were conducted individually in Warsaw, Cracow and in Wrocław, and of groups of managers (also 32 individuals) - at their job locations, individually and as groups, proportionally in the aforementioned cities. The following group of actors and actresses comprising 32 individuals was surveyed (in the alphabetical order): Mariusz Benoit, Ewa Błaszczyk, Tadeusz Borowski, Teresa Budzisz-Krzyżanowska, Stanisława Celińska, Anna Chodakowska, Ewa Dałkowska, Krzesisława Dubielówna, Anna Dymna, Jan Englert, Adam Ferency, Krzysztof Globisz, Krystyna Janda, Krzysztof Kolberger, Mirosław Konarowski, Zofia Kucówna, Olgierd Łukaszewicz, Piotr Machalica, Anna Nehrebecka, Jan Nowicki, Daniel Olbrychski, Jan Peszek, Anna Polony, Igor Przegrodzki, Jerzy Radziwiłowicz, Anna Romantowska, Anna Seniuk, Dorota Stalińska, Joanna Szczepkowska, Krystyna Tkacz, Jerzy Zelnik, Joanna Żółkowska.

The applied psychological methods and statistical analyses for the calculation of results assured the respondents their total anonymity and disable their identification.

\section{Results and discussion}

The results obtained from the surveyed individuals will be presented and described in the following sequence: the picture of oneself, personality related indicators of differences and similarities in the dimensions of the Personality and Axiological Model (competences, relations, autonomy) and a comparison of the system of values. Below, in Graph no. 1, the real pictures of oneself (who I am) are presented. They are the effect of the ACL test in the group of outstanding actors and managers. 
Graph 1. Results of the ACL test (pictures of oneself, me: real) obtained by the outstanding actors $(\mathrm{N}=32)$ and managers $(\mathrm{N}=32)$

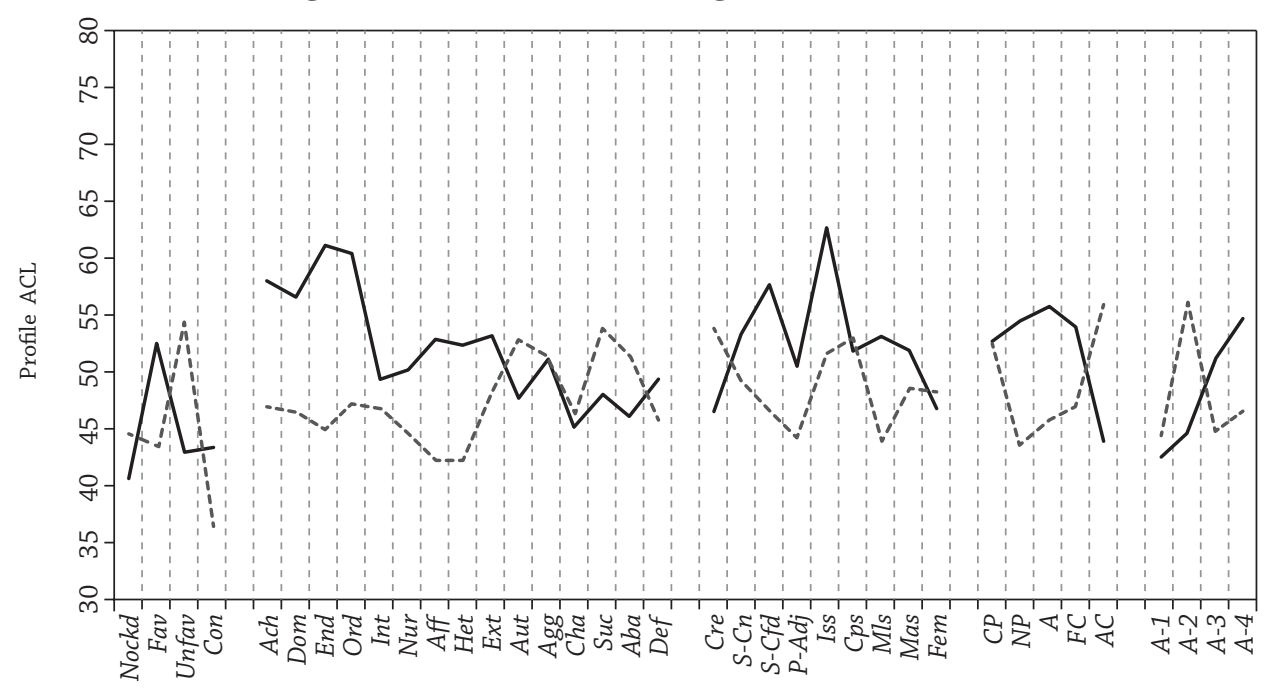

Dotted line - actors, solid line - managers.

Source: Own survey.

The results in Graph 1 show a serious diversity indicating individuality of personalities of the surveyed artists compared to the surveyed managers. The ACL test comprises 37 scales: No Ckd - the total number of adjectives checked; Fav - the number of socially desirable adjectives checked; Unfav - the number of unfavorable (socially undesirable) adjectives checked; Com - Communality; Ach Achievement; Dom - Dominance; End - Endurance; Ord - Order; Int - Intraception; Nur - Nurturance; Aff - Affiliation; Het - Heterosexuality; Exh - Exhibition; Aut - Autonomy; Agg - Aggression; Cha - Change; Suc - Succorance; Aba - Abasement; Def - Deference; Crs - Counseling readiness; S-Cn - Self-control; S-Cfd Self-confidence; P-Adj-Personal adjustment; Iss - Ideal self-picture; Cps - Creative personality; Mls - Military leader; Mas - Masculine; Fem - Feminine; CP - Critical parent; NP - Nurturing parent; A - Adult; FC - Free child; AC - Adopted child; A-1 High origence, low intellectence; A-2 - High origence, high intellectence; A-3 - Low origence, low intellectence; A-4 - Low origence, high intellectence.

The largest differences between the surveyed individuals concern the following scales: Ach, Dom, End, Ord, Aff, S-Cfd, Iss, Mls, NP, A, AC, A-2. Hence, they concern both the need for achievement, self-confidence, the military leader, as well as functioning of the ego as in the light of the transaction analysis.

The surveyed outstanding actors are characterized by a definitely lower order and lower 'stiffness' of their personality, lower schematism of actions, high level 
of spontaneity, missing skill of postponing gratification, lower level of directivity compared to the managers acting in the services sector. Moreover, in the group of the outstanding actors there dominates intuitive intellectence.

The group of managers obtained greater results in the following scales: achievements, maturity, domination, control, self-confidence as well as it is characterized by a certain sustainability in the area of intellectence - there dominates an analytic type (low origence, high intellectence). In the scales of the transactional analysis, the obtained picture shows this group as individuals who are entrepreneurial, autonomous, efficient, focused on their job, authentic, they appreciate hierarchy at work, they can provide advice, they are effective, they control emotions and generally they are satisfied. This group clearly shows higher, compared to the actors, social adjustment arising from positive interpersonal relationships.

Similarities between the surveyed groups should be mentioned. They include similar results in the following test scales: autonomy (Aut), change (Cha), self-control (S-cn), creative personality (Cps), feminine (Fem), critical parent (CP) and high origence, low intellectence (A-1). The results show that the surveyed persons are oriented to professional achievements, success and effective performance. In the light of McClelland's theoretical assumptions (1985), they indicate a strong intrinsic motivation. This type of personality trait, common for both of the groups, indicates no fear in relation to taking action, self-confidence, clearly defined plans, courage and facing challenges. The surveyed individuals do not avoid competition, they look for information contributing to growth of their professional competences, as well as they contact with other people very directly.

The aforementioned results confirmed the existence of a certain and specific transfer of skills, competences and the way of acting (including the motivation sphere). Both of the surveyed groups, due to mutual traits, may mutually use solutions in terms of planning, organizing, motivating and work control. These fields are classic managerial tasks (Stoner, Wankel, 1996).

Table 1 comprises the results of the surveyed individuals in the dimensions of the Personality and Axiological Model (competences, relations and autonomy).

The differences between the results obtained in the Personality and Axiological Model $(\mathrm{N}=32)$ by the outstanding actors/actresses and managers representing the services area $(\mathrm{N}=32)$ show a match in two aspects (dimensions): competences and autonomy (no statistically significant differences) and diversity in the relations at the level equal to $0.001(\mathrm{t}=-3.191)$. It is a result accordant with the assumed hypothesis.

It means that the surveyed outstanding actors and persons professionally engaged at managerial positions in the services sector, that is individuals 
successful at work, present the same approach to their profession, their actions are effective, they have a strong feeling of obligation and they show great cognitive characteristics. Moreover, they are characterized by great autonomy in the area of their actions, self-confidence and independence. In the relations dimension, diversity was observed; more commitment to this category was proved in the group of managers compared to the actors.

Table 1. Differences in the results obtained in the MOA in the group of outstanding actors and managers. Average results (M), standard deviation (SD), t-value, the level of significance of differences $\mathrm{p}, \mathrm{df}=31$

\begin{tabular}{|c|c|c|c|c|c|}
\hline MOA & Groups & M & SD & $\mathrm{t}$ & $\mathrm{p}$ \\
\hline Competences & $\begin{array}{l}\text { actors } \\
\text { managers }\end{array}$ & $\begin{array}{l}48.14 \\
52.11\end{array}$ & $\begin{array}{l}5.53 \\
8.66\end{array}$ & -1.782 & 0.095 \\
\hline Relations & $\begin{array}{l}\text { actors } \\
\text { managers }\end{array}$ & $\begin{array}{l}43.41 \\
57.83\end{array}$ & $\begin{array}{l}6.16 \\
7.03\end{array}$ & -3.191 & 0.001 \\
\hline Autonomy & $\begin{array}{l}\text { actors } \\
\text { managers }\end{array}$ & $\begin{array}{l}51.01 \\
54.69\end{array}$ & $\begin{array}{l}7.64 \\
7.71\end{array}$ & -1.655 & 0.120 \\
\hline
\end{tabular}

Source: Own survey.

The results obtained in the course of the ACL and the MOA surprise by their accuracy and the data can be used to work on professionally engaged creative individuals. Both the differences and similarities concerning the results prove specificity of their personality structures and moreover, the individuality in particular fields gives a great opportunity to estimate the way their professional career is going to follow. This type of results confirms the researchers' opinions that the creative approach is one of personality attributes, which can be worked on (Nosal, 2001; Amabile, Schatzel, Moneta, Kramer, 2004; Wojtczuk-Turek, 2008; Bańka, 2016; Mróz, 2015; Mróz, Osterloff, Kociuba, 2017).

The next table presents the results in the form of a ranking of hierarchy of values obtained by the surveyed individuals, based on the Rokeach Value Survey. In order to assure transparency of the data, only the final results were applied.

Surveys conducted on the basis of the Rokeach Value Survey showed that the most stable are the most and least appreciated values; it is an attribute characteristic for all ranking methods (Rokeach, 1967, 1979). Hence, when analyzing the ranking, the discussion was focused on the most preferred values (the first three ones - in the table in bold) and the most devalued ones (the last three ones - in the table in bold). 
Table 2. Final values in the group of outstanding actors $(\mathrm{N}=32)$ and managers $(\mathrm{N}=32)$

\begin{tabular}{|l|r|r|r|r|r|r|}
\hline \multicolumn{1}{|c|}{ Name of final values } & $\begin{array}{c}\text { Ranking } \\
\text { actors }\end{array}$ & $\mathrm{M}$ & $\mathrm{SD}$ & $\begin{array}{c}\text { Ranking } \\
\text { managers }\end{array}$ & $\mathrm{M}$ & $\mathrm{SD}$ \\
\hline Safety & 11 & 10.77 & 2.61 & 16 & 12.46 & 5.51 \\
Mature love & 8 & 7.94 & 6.11 & 3 & 5.88 & 3.79 \\
Wisdom & $\mathbf{3}$ & 6.26 & 5.83 & 5 & 7.36 & 4.78 \\
Beauty of the world & 4 & 6.81 & 4.68 & 15 & 12.12 & 3.73 \\
Peace in the world & 9 & 8.39 & 3.58 & 10 & 10.53 & 4.93 \\
True friendship & 7 & 7.55 & 3.92 & 6 & 7.41 & 4.10 \\
Enjoyment of life & 15 & 12.58 & 3.85 & 11 & 10.64 & 4.19 \\
Equality of people & $\mathbf{1 7}$ & 13.55 & 4.94 & 12 & 11.59 & 4.91 \\
Outstanding successes & 12 & 11.74 & 4.33 & 9 & 10.36 & 4.33 \\
Self-respect & 5 & 6.87 & 3.33 & 4 & 6.47 & 4.05 \\
Social recognition & 14 & 12.32 & 4.81 & 14 & 11.94 & 3.68 \\
Inner peace and harmony & 6 & 7.00 & 4.24 & 7 & 7.84 & 5.15 \\
Personal freedom & $\mathbf{1}$ & 4.65 & 5.73 & 8 & 8.44 & 3.48 \\
Comfortable life & $\mathbf{1 8}$ & 14.16 & 4.07 & 13 & 11.77 & 11.69 \\
Providing financial & 10 & 9.16 & 5.59 & $\mathbf{2}$ & 5.69 & 4.26 \\
support for the family & & & & & & \\
Salvation & $\mathbf{1 6}$ & 13.16 & 4.47 & $\mathbf{1 7}$ & 12.58 & 5.92 \\
Health & $\mathbf{2}$ & 5.45 & 3.21 & $\mathbf{1}$ & 4.77 & 3.97 \\
Exciting life & 13 & 11.77 & 4.26 & $\mathbf{1 8}$ & 12.59 & 4.82 \\
\hline
\end{tabular}

Source: Own survey.

The outstanding Polish actors put first such final values as: 'personal freedom', 'health', 'wisdom', and the last are: 'salvation', 'equality of people' and 'comfortable life'.

The managers related with the services sector put first such final values as: 'health', 'providing financial support for the family' and 'mature love', and the last are: 'equality of people', 'salvation' and 'exciting life'.

Summing up the hierarchy of the values of the outstanding actors, it is clear that this environment feels serious intrinsic and external pressure and hence, personal freedom seems for this group to be a sort of release. Such a release from the restrictions may also be a picture of specific motivation which art poses for them. The feeling of independence along with concentration on health and the successful life is, to some extent, a frame of the values system for this group. The surveyed individuals reject religious values, egalitarianism, and life without any unnecessary effort.

In the group of managers, individualistic values dominate rather than traditional ones, unexpectedly conservative ones. Devalued values are similar to the system of the group of actors. 
Both of the environments are characterized by a diversified and specific system of preferred values, which confirms the hypotheses.

\section{Conclusion}

The paper presents theoretical concepts explaining the weight of specific needs for groups of individuals engaged into their jobs: outstanding Polish actors and managers representing the services sector. These opinions showed the complexity of the phenomenon of success and focused on the reasons behind the engagement of individuals in their jobs. The needs discovered by McClelland and the author's Personality and Axiological Model (in particular competences, relations, autonomy) enabled to determine variables substantial for the functioning of the surveyed individuals.

The obtained results are very interesting and they show the scope of differences and similarities in the personality structure and the hierarchy of values. It turned out there exists a specific positive transfer of skills, competences and performance, which is a similar motivation sphere among both of the groups.

One of the effects of the obtained results is higher awareness of mutual relations between professional groups. Mutual knowledge of the surveyed individuals originating from varied professional environments about the way of functioning and effective solving of personal and social problems, as well as those arising from the axiological sphere could contribute to a higher level of satisfaction from their life and jobs. A problem preventing the integration of approaches may be a common lack of awareness that in other professional groups similar problems were solved a long time ago and in a defined way. Drawing conclusions from the experience of others makes us reduce the area of making the same mistakes in an effective way. It is unquestionably important information which needs to be applied in everyday life among the described professional groups.

\section{References}

Amabile, T.M., Pillemer, J. (2012). Perspectives on the social psychology of creativity. Journal of Creative Behavior, 46(1), 3-15.

Amabile, T.M., Schatzel, E., Moneta, G.B., Kramer, S.J. (2004). Leader behaviors and the work environment for creativity: perceived leader support. The Leadership Quarterly, 15(1), 5-32. 
Bańka, A. (2016). Proaktywność a tryby samoregulacji. Podstawy teoretyczne, konstrukcja i analiza czynnikowa Skali Zachowań Proaktywnych w Karierze. Poznań - Warszawa: Wydawnictwo Stowarzyszenie Psychologia i Architektura.

Błaszczyk, E., Strączek, K. (2005). Wejść tam nie można. Kraków: Wydawnictwo Znak. Brzozowski, P. (1989). Skala wartości (SW). Polska adaptacja Value Survey M. Rokeacha. Handbook. Warszawa: Polskie Towarzystwo Psychologiczne.

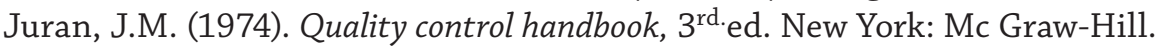

Martowska, K. (2012a). Psychologiczne uwarunkowania kompetencji społecznych. Warszawa: Wydawnictwo LiberiLibri.

Martowska, K. (2012b). Lista Przymiotnikowa ACL - Harrison G. Gough, Alfred B. Heilbrun, Jr. Polska normalizacja. Warszawa: Pracownia Testów Psychologicznych PTP.

McClelland, D.C. (1961). The Achieving Society. New York: Free Press.

McClelland, D.C. (1973). Testing for Competence Rather than for 'Intelligence'. American Psychologist, 28, 1-14.

McClelland, D.C. (1985). Human Motivation. Glenview, IL: Scott, Foresman.

Mróz, B. (2008). Osobowość wybitnych aktorów polskich. Studium różnic międzygeneracyjnych. Warszawa: Wydawnictwo Naukowe Scholar.

Mróz, B. (2011). Poczucie jakości życia u pracowników wyższego szczebla: uwarunkowania osobowościowe i aksjologiczne. Warszawa: Wydawnictwo Naukowe Scholar.

Mróz, B. (2015). 20 lat później - osobowość i hierarchia wartości wybitnych aktorów polskich. Badania podłużne. Warszawa: Wydawnictwo Naukowe Scholar.

Mróz, B., Kociuba, J., Osterloff, B. (2017). Sztuka aktorska w badaniach psychologicznych i refleksji estetycznej. Warszawa: Wydawnictwo Naukowe Scholar.

Murray, H.A. (1938/2008). Explorations in Personality. Oxford - New York: Oxford University Press.

Nosal, C.S. (2001). Psychologia myślenia i działania menedżera. Rozwiązywanie problemów. Podejmowanie decyzji. Kreowanie strategii. Wrocław: Wydawnictwo AKADE.

Rokeach, M. (1967). Value survey. Sunnvale, CA: Halgren Tests.

Rokeach, M. (1973). The Nature of Human Values. London: Sage.

Rokeach, M. (Ed.) (1979). Understanding Human Values. New York: Free Press.

Rotter, J.B., Lah, M.I., Rafferty, J.E. (1992). Rotter Incomplete Sentences Blank. Manual. San Antonio, San Diego, Orlando, New York, Chicago, Toronto: The Psychological Corporation, Harcourt Brace Jovanovich, Inc.

Ryan, R.M., Deci, E.L. (2000). Self-Determination Theory and the facilitation of intrinsic motivation, social development, and well-being. American Psychologist, 55(1), 68-78.

Stoner, J.A.F., Wankel, C. (1996). Kierowanie. Warszawa: PWE.

Strzałecki, A. (2010). Twórczość i prawdopodobieństwo subiektywne osiągania celów życiowych a czas psychologiczny. In: S. Bedyńska, G. Sędek (Eds.). Życie na czas. Perspektywy badawcze postrzegania czasu. Warszawa: Wydawnictwo Naukowe PWN, 307-328. 
Terlecka-Reksnis, M. (2008). Holoubek Rozmowy. Intermedium: Paradoks. Warszawa: Wydawnictwo Prószyński i S-ka.

Wojtczuk-Turek, A. (2008). Rozwijanie kompetencji twórczych. Warszawa: Wydawnictwo Szkoły Głównej Handlowej.

\section{Barbara Mróz}

Associate professor in psychology, in the Institute for Psychology of the University of Opole. She worked for 21 years at the Wrocław University. She lives in Wrocław. She graduated from psychological studies at The John Paul II Catholic University of Lublin; she also defended her PhD dissertation there. During her scientific work she has managed to complete many projects concerning psychology of personality, management and the quality of life. She is the author of many books: Osobowośc wybitnych aktorów polskich. Studium różnic międzygeneracyjnych (2008), Poczucie jakości życia u pracowników wyższego szczebla. Uwarunkowania osobowościowe $i$ aksjologiczne (2011), Functioning in the Workplace. Quantitative and Qualitative Psychological Research (Ed., 2012), Szef X - pracownik Y. Wyzwania w zarzadzaniu pokoleniem Y (Ed., 2014, 2 ${ }^{\text {nd }}$ ed. 2017), 20 lat później-osobowość i hierarchia wartości wybitnych aktorów polskich. Badania podłużne (2015). The last book was awarded the Teofrast prize 2016 for the most popular scientific psychological book. In 2017 two books were published, co-author of which is Barbara Mróz: Sztuka aktorska w badaniach psychologicznych i refleksji estetycznej (J. Kociuba, B. Osterloff) and Kompetencje osobowościowe i twórcze. Psychologiczne uwarunkowania kreatywności pracowników (A. Chudzicka-Czupała, M. Kuśpit). 